\title{
Canadian Films and Understated Critiques of (North) American Suburbanism
}

\author{
Peter Clandfield
}

If the evolution of suburbs and of thinking about suburbs owes much to the geographical scale and material wealth of the North American continent, are the suburbs of Canada different from those of the United States? The sometimescontroversial versatility with which Canadian cities have played American ones in recent film and television productions would suggest that North American urban and suburban spaces are generic and interchangeable —or at least enough so for the requirements of mainstream cultural industries. However, are Canadian representations of suburbs distinctive in ways that matter? I will argue that at least in the cases of two notable Canadian films, they are. I will also, however, address some of the complicated and perhaps contradictory and controversial ways in which Canada itself can be regarded as a cultural, economic, and/or ideological suburb of the United States.

The film industry itself presents perhaps the clearest and most literal instance in which Canada has been a "suburb" - that is, a subordinate satellite territory-to the United States. Since before World War II, Hollywood has dominated film production, distribution, and exhibition in Canada, treating the country as an outlying extension of its domestic market (Gittings 87). With rare exceptions, Canadian movie theatres-particularly suburban ones-have shown the same Hollywood

Peter Clandfield grew up in Edmonton, Alberta, in a neighborhood that was a suburb in the 1950s but is now inner-city. Currently he teaches English at the Royal Military College of Canada in Kingston, Ontario. He has published several articles on representations of place, space, and urban development in contemporary novels and films. Among his other interests are theories and practices of censorship and questions of race and cultural hybridization. 
films as their U.S. counterparts. Profits from exhibition have been ploughed back into Hollywood, while Canadian talent has quite frequently gone the same way. Canada thus can be said to have played the traditional suburban roles of housing consumers for goods produced elsewhere and of serving as a dormitory for those who aspire to success elsewhere. Canadian films have occupied only two to three percent of Canadian cinema screen time (McIntosh 71-72; Magder 232-233) and have been characterized by limited budgets and by outsiders' perspectives.

Don Owen's Nobody Waved Good-Bye has the distinction both of being one of the first feature-length fiction films made in postwar English Canada and, I will suggest, of being something of a pioneering "slacker" film as well. Without evincing crude contempt for suburbanites or particular hostility toward the United States, Nobody Waved Good-Bye uses the frustration and ambivalence of teenagers in the prosperous postwar suburbs of Toronto to offer a critical and ironic perspective on both Canadian identity and (North) American suburban materialism and autothralldom. Nobody Waved Good-Bye finds important parallels in a much more recent Canadian suburban film, Gary Burns's The Suburbanators. Burns's film, made and set in the suburbs of Calgary, a city often seen in contemporary Canada as an upstart western rival to Toronto, is distant from Owen's in space as well as in time. Yet these very distances highlight the significance of the distinct similarities that also exist between the two films. Both present an ordinary, even at times dull, surface, which camouflages sharp observations and intriguing implications about the details and nuances of their suburban settings.

Understatement itself, broadly construed, can be regarded as a staple suburban mode of signification. For one thing, suburbs have been widely marketed as retreats from the noise and stress of the modern city: places, in a sense, of restful auditory understatement. Further, residential suburbs, at least when new, are generally defined by forms of visual understatement, since they commonly consist of large groupings of identical or at least markedly similar houses. ${ }^{.}$This visual minimization of difference and individuality tends to correspond to other forms of homogenization: often noted in both theorizations and fictional representations is that suburban developments are apt (by design and/or by more haphazard means) to recruit and group residents according to their social, economic, and cultural characteristics. ${ }^{2}$

All of the elements just described have helped to provoke critiques of suburban blandness and conformism. A prominent recent example is The Hours, both Michael Cunningham's novel and particularly Stephen Daldry's film version, in which the idea that the quietness and predictability of suburbs is inimical to creativity (and to the psyches of those endowed with it) helps to link three distinct plotlines across space and time. Suburban hours, the novel and film seem to suggest, are inherently less dense with life than are central-city ones. Yet American attacks on the ills of suburbia have themselves been subject to critique. Catherine Jurca argues that such attacks are often "predicated on [the] disavowal of the very real privileges that the suburb has offered those who live there" (6), and she points out that "[d]enunciations of paradise are one of its staple pastimes and prerogatives" (168). In other words, the extent and magnitude of suburbia's shortcomings can be exaggerated, and there is nothing necessarily subversive in attacks upon them. 
Both Nobody Waved Good-Bye and The Suburbanators adopt suburban modes of understatement and adapt them into forms of parody in order to indicate some of the overstatements, omissions, and ideological simplifications of dominant suburban representations and discourses. In so doing, they notably avoid both utopian idealization and pessimistic condemnation of suburbia. I will devote most of my space to The Suburbanators, touching on its parallels to and differences from Nobody Waved Good-Bye (which offer a rough index of some developments, and continuities, in Canadian suburbia from the 1960s to the 1990s), then focusing on its treatment of contemporary suburban space as an arena for the negotiation of cultural difference and for the development of cultural hybridity. I will compare it in this respect, and others, to U.S. takes on contemporary suburbs, particularly that of Richard Linklater as featured in SubUrbia. Burns's film is neither an imitation of American films nor a direct attack upon them. Rather, like Nobody Waved GoodBye, it presents itself implicitly as an alternative or supplement to better-known texts.

Canadians have long been anxious about what they perceive as escalating U.S. influence (Gittings 104), and Canadian cultural products have often defined themselves in opposition to U.S. models. However, this opposition has increasingly gone beyond assuming the purely defensive stance of an underdog struggling valiantly against monolithic oppression. For example, The Beaver Bites Back?, a wide-ranging 1993 collection of essays, raises - first of all through its title - the possibilities of popular culture as a site of indirect resistance, revision, or evasion of American influences. One of the volume's editors, Frank E. Manning, argues that "Canadians import and eagerly consume American cultural products but reconstitute and recontextualize them in ways representative of what consciously, albeit ambivalently, distinguishes Canada from its powerful neighbour: . . . social democracy, $\ldots$ official multiculturalism, ... institutionalized compromise, $\ldots$ and so on" (8). Manning also compares Canadian popular cultural forms to the cargo cults of colonial New Guinea and their "subversive parody" of dominant models, arguing that the analogy "helps to highlight a set of dynamics that are structurally comparable to those of the Canada-U.S. relationship, .... [including] a peculiar and paradoxical blend of imitation and inversion, complementarity and contrast, transfer and transformation" (7). Parody is most commonly and obviously based on exaggeration and simplification of its object - as in, to cite a virtually inescapable example, the work of Canadian suburban export Mike Myers in the Austin Powers series. Dan Harries, defining parody as "the process of recontextualizing a target or source text through the transformation of its textual (and contextual) elements" (6), focuses on broadly comic films and emphasizes their reliance on "spoofing traditions" (11-21). ${ }^{3}$ Drawing on the theoretical work of Mikhail M. Bakhtin, Harries argues that mainstream forms of parody have themselves come to constitute a tradition, a canon, and may thus have compromised their subversive potential (21). I will argue that Nobody Waved Good-Bye and The Suburbanators, however, employ an alternative form of parody, which they develop through de-dramatization and complication not so much of specific individual "target" films as of a range of textual and contextual materials concerning suburbia. 
Nobody Waved Good-Bye was inspired by much the same suburban Toronto environment that spawned Myers-who was born in 1963, the year Owen's film was made, and who was honored in 2002 with a street-naming in his home territory of Scarborough, the large eastern Toronto suburb whose perceived dullness has earned it the nickname "Scarberia." Owen's film is set on the other side of Toronto, in the western suburb of Etobicoke, which, in parallel with Scarborough, grew rapidly in the 1950s and early 1960s, in a process that was facilitated by the postwar prosperity of Southern Ontario and that resulted in what Canadian pop-culture historians Geoff Pevere and Greig Dymond have called the "vast, indistinguishably meshing suburban spill" that now surrounds Canada's largest city (186).

Owen, himself a Torontonian, chose the locations for Nobody Waved GoodBye. He is a self-described former "sloppy bohemian" (102), and his work on the film links him to the more contemporary figure of the improvising independent/rebel filmmaker, such as Linklater (see Pierson 187), and thus also raises the paradoxical point that making films about slacking requires particular amounts of initiative and perseverance. Owen was meant to be making a half-hour docudrama about juvenile delinquency for the National Film Board of Canada, which he had joined in 1960 at the age of 25. Reportedly, though, he took advantage of circumstances to obtain sufficient film stock to shoot an eighty-minute feature (Magder 100). Not surprisingly, the film draws on the documentary styles in currency at the NFB when it was made, and its use of black-and-white stock, hand-held camerawork, location sound, long takes, and improvised action and dialogue amounts to a critique-in-action of Hollywood glitz. The fact that the film exists at all is an implicit challenge to Hollywood domination of Canadian screens. However, it had lukewarm reviews when it opened in Canada in 1964, and not until it was praised by major American media such as The New Yorker in the spring of 1965 was it widely appreciated in its home country (Owen 5-7, 94-100). This reception history reinforces the film's own suggestions about Canadian cultural uncertainty and provides an instance of Canada as an intellectual suburb of the U.S., a margin taking its cues from the center.

The opening sequence of Nobody Waved Good-Bye finds the central characters, Peter and Julie, skipping high school on a spring afternoon. Peter's opening nearmonologue introduces two of his key traits, loquaciousness and aimlessness: "I really don't know ... where I wanna go and what I wanna do, but I can tell you ... I can tell you without a minute's hesitation what I don't wanna do. I don't want to get into the kind of rut my parents are in." His hesitation in this very utterance serves to hint that his words will be unreliable, as indeed they regularly prove throughout the film. As Seth Feldman has noted, Peter is "a kind of anti-prophet" (53). He does not trust the life modeled in suburbs around him, but can only articulate negatives.

Both Peter's negativism and the film's complex methods of signifying through him are captured in an early sequence in the living-room of his family's neat and spacious split-level house. He talks with—or at—his sister's dapper, pipe-smoking dentist fiancé, Ron, and soon subjects him to largely-unprovoked accusations of mindless materialism and conformism: 
You're making a lot of money; you're putting teeth in people .... I mean, did you ever . . stop to take a look at the kind of life you were leading? ... . Or d'you, d'you just sort of live without, without any, any goal or any reason for it? . . . I I bet that's the kind of life you live, isn't it? I mean, isn't it? You just-I mean, why are you going to Cleopatra tonight? What d'you waste seven bucks for? Just because everybody else is doing it!

If the film draws attention here to the prominence in Canadian suburban life of American products like overblown blockbuster movies, it complicates its own stance toward U.S. culture and suburban leisure pursuits by voicing its commentary in Peter's strident yet hesitant tones. Ron's response to the harangue just cited is not unreasonable (indeed, understated): "Peter, you know you're getting a little obnoxious?" With his pipe, blazer, and slacks, Ron is visually a caricature of a suburban gentleman-figure, but he is depicted as bland and baffled rather than as contemptible. ${ }^{4}$ Paradoxically, the ambiguity created by Peter's overstatement in sequences like this contributes to the understated effect of the film as a whole: both the sequence and the film suggest suburbia's discontents, but refuse to oversimplify their sources or their solutions.

The film's subtlety emerges also in its treatment of cars and the ironic way in which they are at once partly responsible for the spread of low-density North American suburbs and yet the most obvious vehicles for escape from those suburbs. If cars in Hollywood films often function as personality-extensions for characters, in Nobody Woved Good-Bye (and The Suburbanators) they relate more clearly to what characters lack. Peter claims to disdain American culture, but cars become key to his aspirations to escape the suburban "rut." His father is a car salesman, and Peter's first real act of rebellion occurs when he goes for an unsanctioned joyride with Julie in a demonstrator convertible that his father has brought home. Predictably, he drives carelessly and runs a red light. "All the cops are in the middle of the city," he assures Julie. This is one of his anti-prophecies and also, perhaps, a symptom of suburban obliviousness: a police car immediately appears behind him and pulls him over. He is arrested for dangerous driving and taken to the cells of a nearby police station.

More than a few viewers of the film have nicknamed Peter "rebel without a car," and, while Nobody Woved Good-Bye is no full-scale parody of Rebel Without a Cause, the police-station sequence can be read as a parodic de-dramatization of the opening sequence of the landmark 1955 Hollywood suburban drama. The contrast between the two films is above all stylistic: while Rebel itself is complex and is critical of dominant American ideology, it also exemplifies dominant Hollywood methodology in, among other things, its glamorization of stars (as well as cars). In contrast, the actors playing Peter and Julie, Peter Kastner and Julie Biggs, were chosen by Owen specifically because they were more ordinary than beautiful (Owen 103). Moreover, the hesitations and stumbles that come with Kastner's and Biggs's improvisations (which are highlighted by the film's technical improvisations) throw into relief the artificiality even of the celebrated Method acting of James Dean in Rebel - and, in turn, call into question the relevance of Rebel to everyday suburban concerns. ${ }^{5}$ 
After his dangerous driving episode, Peter leaves home and moves to a rooming-house, relying for transportation on his small motor-scooter and on Toronto's subway system. He shoplifts, fails his matriculation exams, disrespects his probation officer, and skirmishes with several dull, low-paying jobs. He and Julie plan vaguely to save money and go to Europe. Eventually, he takes a position as a parking-lot attendant. Here, though, his problems with cars and with petty crime converge: he is coerced into a scheme for earning "dividends" (that is, shortchanging patrons) by the lot's crooked manager, John, who then demands "three bucks a day" from Peter as his cut of the ill-gotten gains. John is the closest thing the film has to a villain, but his menaces are comically non-violent, consisting almost entirely of a threat to turn Peter in to the police unless he plays along. The character adds fortuitously to the film's parodic dimension, for he is played by John Vernon, the film's most recognizable actor, who would soon go to Hollywood to play more seriously sinister figures. ${ }^{6}$

Desperate to escape his situation, Peter empties the till at the parking lot and steals one of the cars there. Significantly, the Triumph sports car he chooses first is locked, and he is forced to abandon this symbol of glamourous individualism (and of Canada's British past) and settle for a General Motors family sedan, a metonym for suburban North American ordinariness. Peter collects Julie and they set off down the highway, but when he admits his thefts, she insists that he pull over. He does so, and she reveals that she is pregnant and demands that he return to the city with her to face the consequences of his actions. He cannot commit to doing so and drives away alone and in tears as the film ends. Leslie Felperin observes that "realist suburban films are the opposite of the road movie: they're the 'going-nowhere' movie" (16). Felperin has in mind recent works (including SubUrbia), but this formulation applies equally well to Nobody Waved Good-Bye. Owen's 1984 sequel to the film, Unfinished Business, which deals with the rebellion of Peter's and Julie's daughter, finds Peter (divorced from Julie) living in the suburbs, still annoying and now also slightly smug. Thus, both in its details and in the basic fact that it treats Peter's and Julie's story as meriting a further installment twenty years on, Owen's work ultimately suggests the inescapability for Canadians of suburbia and also, implicitly, of some degree of U.S. influence.

What strikes today's Canadian viewers most about Nobody Waved Good-Bye may be the homogeneity of its Toronto. ${ }^{7}$ The closest thing the film features to ethnic Others are two British-accented male authority figures, a job interviewer and a landlord, both of whom Peter treats with nonchalant rudeness. The degree to which Canada's demographics have changed since the 1960s is acknowledged in The Suburbanators. The cultural hybridity of contemporary Canada is strongly evident in Calgary, even though it is a somewhat less spectacularly diverse city than Toronto, and Burns's film both draws attention to this fact and, I will argue, links it to a view of suburban possibilities that is, in a muted and irony-laden way, more optimistic than those of either Nobody Waved Good-Bye or SubUrbia.

Calgary is a particularly appropriate setting for a film on contemporary Canadian suburbs. The nearby discovery of oil in 1947 fuelled rapid growth that has, with brief interruptions, continued since. Between approximately 1940 and 1970 the city 
quadrupled in both area and population, and it now extends over the foothills of the Rocky Mountains to the west (as well as over the prairie to the north, south, and east) in a way that makes it one of the most visibly suburban of Canadian cities. Calgary's relative newness and prairie location have provoked a certain amount of disparaging commentary from other parts of Canada on its perceived featurelessness. The city is sometimes seen as a prime Canadian manifestation of much the same kind of (supposed) suburban wasteland that Edith Wharton attacks in her 1925 essay "The Great American Novel," where she asserts that "the safe and uniform life resulting from" suburban conveniences "offers to the artist's imagination a surface as flat and monotonous as our own prairies" (qtd. in Jurca 3). Work like Burns's counters such lofty dismissals of suburbia's imaginative potential. ${ }^{8}$ Calgary also tends to be perceived within Canada as an outpost of creeping Americanization, thanks in part to the relatively entrepreneurial and individualistic culture that economic prosperity has fostered, and this image makes it an especially intriguing setting for the ironic and gently un-American view of suburbia that Burns presents.

Burns wrote and directed The Suburbanators as his first feature. Like Nobody Waved Good-Bye, the film owes its existence to communal/institutional support, having been made (during the fall of 1994) with equipment that Burns borrowed from the Calgary Society of Independent Filmmakers. Yet The Suburbanators also exhibits parallels with Linklater's films. They share a concern with evoking both generic features of North American urban and suburban environments (systembuilt houses, strip-malls, etc.) and a definite sense of place (on this combination in Linklater, see Felperin 15). There are also parallels involving a loose, episodic, movement-based sense of structure, which emphasizes the largely random intersections of characters within a well-defined space. However, Linklater's methods are often notably poetic and dramatic: his films foreground colorful characters and their animated conversations on sex, death, and other intrinsically dramatic topics. ${ }^{9}$ Linklater's recent animated film Waking Life is particularly poetic. Not only does it parallel films with dreams, but it also links dreams with urban and suburban space: its animation (though reality-based) creates generic rooms and streets that become freely available for adaptation by the subconscious. Burns in The Suburbanators, though, is consistently and pointedly prosaic. One Canadian critic, Katherine Monk, calls the film "a defiant middle finger salute to the American road movie tradition" (97), but I will argue that it constitutes a less flamboyant and somewhat more equivocal gesture toward U.S. models: it is a moderately critical reworking of the American suburb- and slacker-movie traditions.

The Suburbanators takes place on a single Fall Saturday afternoon and follows the only-barely-overlapping movements of three separate sets of young men in their early twenties as they travel Calgary's western residential areas. The film's preference for understatement extends to its methods of conveying a sense of place: it avoids establishing shots of major Calgary landmarks (such as venues from the 1988 Winter Olympics) and alludes to the city's celebrated association with rodeos and ranching only through incidental shots of a cowboy-costumed figure promoting a mall and of sedate square-dancers inside it. The film even uses understated examples of suburbia itself: for the most part its action takes place not 
in the city's newest subdivisions but in neighborhoods that were built in the 1950s and 1960s and that might be best described as matured suburbs. Thus, the film serves as a reminder that even subdivisions develop histories and evolutionary lives of their own and that many if not most neighborhoods in North America's newer cities began as suburbs.

The first of the "suburbanators" to appear are $\mathrm{Al}$ and $\mathrm{Bob}$, the only ones to enjoy the use of a car. Al's 1980-something Chrysler K-car, a model no less ubiquitous in the recent past in Canada than in the U.S., is oldish, but in no way distinctively so; as such it is an emblem of the film's prosaic style. It also contrasts notably with the vintage 1960s vehicles featured in Linklater's Slacker, which contribute to that film's evocation of something approaching a cohesive slacker aesthetic and culture. The Suburbanators is simply about various individuals who exhibit various kinds of moderately aimless behavior. Perhaps a "suburbanator," then, is a kind of apprentice slacker.

Al wants to break up with his girlfriend but cannot quite get up the nerve or the energy. Bob drinks beer in Al's passenger seat and philosophizes. Both are notably given to effusions of shallow sexism; indeed, the film appears in its early stages as though it will focus on their sexual aspirations. Al and Bob thus provoke comparison with the protagonists of such American suburban/slacker comedies as Kevin Smith's contemporaneous Mallrats. However, Mallrats (unlike Smith's breakthrough film, Clerks) relies on repetitive and usually under-nuanced visual and sexual humor. Despite occasional moments of satirical sharpness, it devotes little time to challenging or even contextualizing either the sexual attitudes of its characters or received notions about suburban consumerism, which it mocks in predictable ways but also, in the end, celebrates. ${ }^{10}$ The Suburbanators, on the other hand, has noticeably marginalized $\mathrm{Al}$ and $\mathrm{Bob}$ by its conclusion, as if to suggest that their hormone-driven pursuits are insufficiently interesting to provide the central material for a feature-length film.

As The Suburbanators progresses, even $\mathrm{Al}$ and Bob themselves seem intermittently aware of their own puerility. Bob theorizes idly on the relations between automobiles and male sexuality, asking a bemused $\mathrm{Al}$ if his car is his penis. Monk reads this as an overt attack on American "phallo-nationalistic" celebrations of cars and roads (97). But Bob is reliant on Al's car, so his musings do not seem to represent any kind of definitive statement by the film, which puts cars in their place less by attacking them frontally than by not paying them too much attention. Monk is much more persuasive in describing the film as "a study of the pedestrian-in every possible sense" (336). The second set of characters, Eric and Carl, are literal pedestrians and also bus users. Eric is even-tempered and thoughtful; Carl, on the other hand, is hypersensitive and hypercritical. Like Peter, he talks too much and exemplifies the slacker combination of opinionation and aimlessness. Still, he gets several of the film's most resonant lines. Commenting indignantly on what he sees as another character's overdone outfit, he proclaims, "I go out of my way to look as generic as possible." Here he could almost be suburbia itself talking; he could also be the film disclosing its strategy of deliberate, systematic creation of understated effects. 
Carl serves to draw further attention to the film's methods in a sequence that begins when he and Eric, waiting at a bus stop, are offered a ride by an acquaintance, Jim. Carl has quarreled with Jim and is only just persuaded to accept the ride, which he spends making derisive remarks about Jim's battered Toyota. After Jim drops them off, Carl explains his attitude in a tirade whose profanity is counterpointed by muzak issuing from the mall they are standing outside:

The guy takes humility to an extreme and it's fucking aggravating.... I mean, the guy just published a fucking novel and won some big fucking prize with the thing .... I mean, the guy's some kind of modest-aggressive and it really pisses me off .... He could be fucked-up about it, or anti-something. He just seems too satisfied.

This episode manages to anticipate and invert (even pre-parody) the central event in SubUrbia: the stretch-limousine return of a newly-successful rock star, Pony, to his home suburb. While Pony's friends resentfully see him as irreversibly altered by stardom, Carl is annoyed that Jim (whose "big fucking prize" is a relatively modest $\$ 50,000$ ) has failed to turn against his suburban origins. Carl's own annoyingness here further advances the film's own "modest-aggressive" strategies, implying that being "anti-something" is a simplistic response to suburbia.

Much as Nobody Waved Good-Bye does with Peter, The Suburbanators uses Carl to voice ideas, while frequently suggesting the aimlessness of his own views and the relative triviality of his complaints; it thus implicitly acknowledges the shelteredness of middle-class life. Burns's film offers somewhat more positive and concrete alternatives to the vision of suburban aimlessness than does Owen's. The third set of characters — carless like Eric and Carl—is crucial to the more positive ideas about suburbia that the film presents and serves to extend the film's concerns beyond the petty dissatisfactions of suburban/slacker life and into issues of representation. This group consists of three young men, Salah, Kareem, and Roger. Among themselves they speak Arabic, as Kareem explains patiently to a fellow bus passenger who takes an interest in them as they travel down a suburban street:

"What language is that you're speaking?"

"Arabic."

"Arabic. Really?"

"Yup."

"That's interesting. I always thought Arabic was more throaty, or harsher. Y'know, like, rhrrrrh."

"Nope."

"Sure that's Arabic?"

"Yeah, I'm . .. sure."

"Course, y'know, if you did speak with a throatier, harsher sound it could work against you, too .... I I mean, y'know, how . . the way things are ... y'know, politics and all."

Before turning his attention to Kareem and his friends, the passenger has been attempting to engage the bus driver in a discussion of Speed, the then-recent bus 
suspense movie starring exported Canadian Keanu Reeves." Thus, his obtuse questioning of Kareem appears to exemplify the sort of random encounter with eccentric and/or irritating individuals that occurs routinely on public transport. However, it can also be regarded as representing the sort of routine brush with ignorance that immigrants and linguistic minorities must deal with in North America. Certainly the sequence, like others involving the Arab characters, addresses their ethnicity in complex ways. It alludes to "politics and all," and the range of thorny contemporary issues involving Middle Eastern peoples and cultures, yet depicts these particular Arab-Canadians as ordinary. While Kareem is the only one of the trio to speak English, he does so without an accent-or, rather, with a Canadian accent that is indistinguishable from those of other characters in the film, including his irritating interlocutor.

Kareem's, Salah's, and Roger's speech in Arabic is not subtitled, which in itself would seem to emphasize their foreign qualities. Yet the lack of subtitles also forces the viewer to focus more closely on their visual presence and their actions, and such focus renews awareness of their ordinariness, for most of their activities are connected with the archetypal white suburban male activity of playing in a band (see Pevere and Dymond 184-187). Through them, the film recontextualizes this pursuit. Overall, the trio embodies not the foreign-ness of obvious immigrants but the hybridity of people whose everyday lives mix elements of more than one culture, thereby transforming understandings of both. In turn, they evoke on a larger scale the hybrid potential of their environment itself, illustrating one aspect of what Roger Webster has recently described as "the general cultural hybridity combined with social heterogeneity" that characterizes contemporary suburbia (6). ${ }^{12}$

The key sequence in The Suburbanators further develops both this attention to hybridity and heterogeneity and the film's take on the intricacies of suburban space and its representation. The sequence finds all three groups of characters converging on a suburban block near the mall. Both Carl and Eric and $\mathrm{Al}$ and Bob head toward the home of a small-time drug dealer, Tim. Burns explains that "[d]rug culture is one issue in the film, but drug culture of the mild variety: pot-smoking" ("Director's Statement"). By this point, the film has established the Arabic trio as a little more purposeful than the other groups: their band is scheduled to play a gig that evening, but Salah has fallen out with his girlfriend and she has locked their instruments in her apartment, so their actions revolve around efforts to retrieve them, and their quest takes them to a house across the back alley from Tim's.

Despite their lack of a car, Eric and Carl reach Tim's ahead of Al and Bob. As Tim argues with his girlfriend, Cindy, who resents his dealing, Eric visits an upstairs bathroom. While he is there, police raid the house. The police party includes a videographer, and Burns plays on the iconography of reality-TV shows such as Cops, cutting in bumpy video footage of Tim's and Cindy's arrest. Dean MacCannell has observed that Cops "provides a unique, spontaneous glimpse of neighborhoods across the United States" (127n). Burns's brief allusion to the well-known show helps to draw attention to the implications of the sequence as a commentary on Canadian, or at least Calgarian, suburbs. More specifically and more importantly, though, the allusion provides an example of the kind of fast-paced, action-oriented, 
and morally simplified material that the film as a whole conspicuously avoids.

Part of what the sequence emphasizes is the adaptability of suburban space. Eric, hearing the police arrive, is able to climb through the bathroom's dormer window and onto the house's roof. As he crouches there, unsure what is happening below, female laughter issues from the house next door, accompanied by vague slapping sounds. The origin of the sounds remains unexplained, and this auditory vignette, by indicating that there are other stories taking place alongside those the film covers, stresses the spatial complexity, even the mystery, of residential neighborhoods. It also, perhaps, offsets the film's male-centeredness by inviting us to laugh at the male characters and their antics.

Such antics are amply present in this sequence. Once he has climbed laboriously down from the roof and reached the alley, Eric realizes that the police are still in the area and takes refuge in a wooden garbage bin. It proves already to contain Carl, who explains that he has escaped through the house's back door. Across the alley, Salah and Roger, who are kicking around a soccer ball while Kareem tries to negotiate the release of their instruments inside the house, react with understandable surprise and curiosity to the minor spectacle Eric and Carl are creating. Here, as in the bus sequence described above, the Arab characters are ordinary bystanders to eccentricity rather than embodiments of it. The sequence mixes their points of view from the alley with Eric's and Carl's from inside the bin. Once the police have gone, Salah and Roger advance cautiously. They whistle at the bin; inside, Eric and Carl fret but do not respond. So Roger lobs a series of small rocks at the lid of the bin. The noise provokes Eric and Carl to leave their refuge. They emerge abruptly, looking confused and glaring indignantly at the other men as more rocks arrive. Carl retaliates by side-arming a small rock back. A brief, slow-motion battle ensues as Eric and Carl retreat down the alley. None of the rocks are thrown hard. None hits anybody; none seems intended to hit anybody. While nobody actually says anything, this muted confrontation is the closest thing to conversation among any of the three groups in the film. The exchange acknowledges the possibility of interethnic conflict, but its desultory nature also shows that such conflict need not be spectacular or particularly violent.

Pertinent here are Burns's own comments - which are much more directly "antisomething" than is the film itself — on the presence of Kareem, Salah, and Roger: "The inclusion of the Arabic-speaking characters, and their portrayal as average guys with the same problems and concerns as the other characters, is the antithesis of the now common and absurd Hollywood characterization of Arabs as terrorists. However, their characters run deeper than just anti-stereotype and their inclusion exposes the pervasiveness of suburban values" ("Director's Statement"). The film perhaps most directly targeted by Burns's remarks is a Hollywood celebration of the utopian possibilities of suburbia, Back to the Future, whose hero Marty McFly, played by expatriate Canadian suburbanite Michael J. Fox, defeats a vanload of homicidal Libyan terrorists in a mall parking lot. ${ }^{13}$ While it would be too much to term the rock fight a direct parody of McFly's exploits, this part of Burns's film can be said to have a parodic relation to Back to the Future, since (in Harries's terms as cited above) it transforms the Hollywood film's contextual elements-suburbia, 
Arab-North American conflict-into a new and contrasting sequence of text. Moreover, the rock-lobbing episode definitely plays on and implicitly critiques popular imagery of Arab people and Arab culture. Rock-throwing Arab youths have become icons of intractable international conflict, but the basis of this episode in trivial circumstances to which the ethnicity of those involved is incidental serves as a reminder that inter-ethnic conflict arises from specific historical situations rather than from essential racial or cultural characteristics.

Strong parallels have been noted between the suburb and the colony: each has been "politically and economically dependent on" (Archer 27) and/or "placed in opposition to" (Matthews 174) the metropolis. The Suburbanators illustrates suburbia taking its share in the postcolonial hybridization of cities. Other Canadian films offer more sustained and detailed takes on contemporary urban and suburban hybridity,${ }^{14}$ but the very understatement, even casualness, of Burns's treatment of the Arabic-speaking trio is a crucial part of its value. While the rock-lobbing episode at least evokes the possibility of intercultural conflict, its indecisiveness and understatedness, like the unremarkable, even mundane presence of the trio within the film's milieu, reflects the ordinariness of cultural diversity in contemporary Canadian suburbs. Implicitly, through its depiction of suburban alley space as a buffer zone which affords room for maneuver and compromise, the film advances the hopeful idea that Calgary's, and more generally Canada's, suburbs can facilitate relatively peaceful coexistence for diverse groups of people. There may be a danger of nostalgia here - of falling back on a utopian vision of suburbia as the home of infinite supplies of horizontal space. Yet this does not invalidate the film's basic suggestion that contemporary suburbs can still be thought of as places where potential conflict can ebb away.

There are further stages to Kareem's, Salah's, and Roger's progress through the film: they eventually succeed in retrieving their instruments, though not without a brief skirmish with the uncooperative landlord. They go on to be questioned by police at the restaurant where they serve as house band. However, the film reveals this, along with the information that the local tabloid has described the incident under the headline "Immigrants Rough Up Local Landlord," only in a brief sequence of end-titles, which also informs us of the more mundane endings to the other characters' days. (Eric and Carl, for example, spend their evening having pizza and playing cards with Eric's parents, in a further example of the film's testimony to the elements of privilege and safety that form an upside to the blandness of white, middle-class suburban life.) The fact that the film includes no visual representation of the encounter with the police, presumably the most dramatic part of the trio's day, and presumably the part that a show like Cops would be interested in exclusively, ${ }^{15}$ reinforces its emphasis on the ordinary aspects of their lives.

A useful comparison can be drawn between the rock fight (or non-fight) in The Suburbanators and the much more overtly dramatized contestation of suburban space between locals and immigrants in Linklater's SubUrbia. The film, based on Eric Bogosian's 1994 play of the same name, is organized around the archetypal convenience store at "The Corner," on which the film's group of under-employed post-high-schoolers hang out and to which their newly-successful rock star friend, 
Pony, returns in his limo, as noted above. The store's owners are a young Pakistani, Nazeer, and his wife. Nazeer is not depicted in a particularly unsympathetic way, but he is rarely treated as someone with individual traits and aspirations beyond the traditional immigrant ones of material success through hard work. He alternates between being persecuted by the rowdier slackers, perpetually drunk or stoned Buff and sullen, sarcastic, and racist Tim, and lecturing them on their obvious deficiencies. The most thoughtful and sympathetic of the slackers, Jeff, pleads with his friends for tolerance of Nazeer and his wife: "They're just people!" This is exactly what The Suburbanators manages to demonstrate - rather than simply to assert—of its immigrant characters.

Nazeer is more or less defeated at the end of SubUrbia. Buff, whom Nazeer has not unreasonably diagnosed as "a drunk and an idiot," goes improbably off to success and romance in Hollywood, leaving Nazeer and Tim confronting each other with guns outside the store while Jeff tries ineffectually to intervene. At this point, however, Tim gets the opportunity to redeem himself: having climbed onto the store's roof and fired his gun into the air, he discovers there, comatose, another of the film's aimless young people, Bee Bee, who has mixed drugs and alcohol. He becomes purposeful, calls an ambulance and rather unjustly blames Nazeer for her state: "If she dies, you're going to be so sorry you ever showed your brown face in this town!" Nazeer can only lash out (also unjustly) at Jeff, before retreating into the store: "You people are so stupid! ... . You throw it all away!" The film itself maintains an ironic view of the apparent triumph of stupidity and violence; at the same time, it holds up Jeff as someone who will continue to try to do the right thing. Moreover, the confrontation between Tim and Nazeer serves to evoke the same dangers of hair-trigger paranoia that Michael Moore addresses in a more recent and even more critical take on American suburbia in Bowling for Columbine. Yet the film suggests that the negotiation of suburban territory is something of a zero-sum game, which must have winners and losers. Further, the film seems to foreclose on the possibilities of suburbia as a potentially hybrid space, or indeed as anything other than a place to leave. In this way it is at odds with Slacker and Waking Life, which in following their characters' peregrinations treat suburban settings as part of ordinary urban space. Linklater is notably skilled at reworking and questioning mainstream cinematic devices; the fact that he relies on melodramatic violence in SubUrbia may be an indication of the strength of contemporary U.S. anxiety about suburban dysfunction.

Implicit in what I have said thus far is the possibility that Canada functions as a "suburb," an outlying territory, to the United States not only in the dependent or subordinate senses I have mentioned, but also in a more active, if also more metaphorical, sense: that of being connected materially and intellectually to U.S. culture, yet still at sufficient distance to assess that culture critically. It may be tempting for Canadians to go further and see their country as a kind of utopian suburb of the North American continent: a spacious, clean place, on the edge of nature, which offers refuge from the perceived dangers of the "downtown" United States. Such a view could be fostered by Moore's (Canadian co-produced) Bowling for Columbine, which contrasts the media-fuelled fear and paranoia of U.S. suburbs with 
what - using somewhat selective editing - it depicts as the essentially gentler and saner culture that prevails in Canadian ones. ${ }^{16}$ However, if left unqualified and/or taken over-literally, such a view would serve to obscure the fact that Canadian cities and suburbs share at least some of the problems of U.S. ones.

For example, both Toronto and Calgary are notable sites of urban sprawl, whereby new subdivisions replace farmland with streets of large, closely-packed, near-identical houses. In a recent speech to the Canadian Home Builders' Association, Canadian federal cabinet minister David Collenette suggested that governments may need to regulate the development of such land-hungry and potentially-wasteful projects; one industry spokesman responded by insisting that "market forces determine the way a city grows" (McCormick HS03). The large suburban areas of Toronto and Calgary wield considerable political influence and have helped, in recent years, to elect neo-conservative provincial governments in both Ontario and Alberta. These political developments within Canada, coupled with the liberalized economic relationships that have been ascendant over the last fifteen or so years within North America as a whole, have helped to produce the possibility that the continent's wealthier suburbs may increasingly form their own powerful cultural constituency, one often able to bypass governmental regulations and political borders in the pursuit of unregulated use and consumption of land and other resources. ${ }^{17}$ Burns's second feature, Kitchen Party, filmed in the suburbs of Vancouver, addresses this possibility through its depiction of a group of wealthy, right-wing, middle-aged suburbanites who gather at a party in one couple's vast home in a new subdivision, where they ill-temperedly compare their children's prospects, disparaging all forms of education that do not seem likely to lead directly to lucrative jobs. Meanwhile, the children themselves hold their own party in another family's home in an older suburb: the film suggests an intriguing reversal, whereby an older generation appropriates the newest residential areas, leaving the younger generation to adapt existing urban and suburban structures for their own purposes.

Canadians themselves, I would argue, need to pay more attention to "pedestrian" representations, such as Burns's, of their own cities and suburbs. I am definitely not claiming, though, that Canadian views of suburbia are inherently more perceptive, nuanced, or valuable than American ones. ${ }^{18}$ Bakhtin demonstrates that there are forms of parody that, rather than discrediting their objects, bring out their "creative potential" by showing how their details can be adapted into the service of new ideas (Morson and Emerson 434). The Canadian films on which I have focused have a dialogic relationship with better-known American representations. These films do not demolish established understandings of (North) American suburbia; rather, they adapt, recycle, and renovate. My aim in discussing these films has been to highlight some of the possibilities of understatement, parody, and de-dramatization as strategies for the representation of quotidian suburban life. In closing, I would emphasize that these possibilities, as illustrated by films like Owen's and Burns's, are themselves indications of the relative privilege that Canadian suburbs, and those interested in them, still, for the moment, enjoy. 


\section{Notes}

${ }^{1}$ In fact. certain kinds of understatement are enforced in certain kinds of suburbs. For example, Dean MacCannell refers to "the rules requiring 'earth tone' exterior home colors in some Orange County neighborhoods" (121). On the (perceived) visual homogeneity of suburbs, see also Webster 4.

${ }^{2}$ For theoretical and historical commentary on suburbs as sites of social differentiation, see Archer 28-29. For an intriguingly ambiguous fictional take on the same issue, see Alice Munro's "The Shining Houses," a 1968 short story about the process by which the neat new structures named in the title displace a rougher, semi-rural way of life on the outskirts of an un-named Canadian city.

${ }^{3}$ For a discussion of the importance in parody of exaggeration itself, see Harries 83-89.

${ }^{4}$ Ron looks remarkably like a figure from 1950s Life magazine clothing or lifestyle advertisements (see, for example, Wool and Unifast).

${ }^{5}$ Richard Maltby suggests that "[i]n many respects the 'realism' of Method acting in the 1950 s, like that of the widescreen technology it coincided with, can be thought of as a kind of excess, packaged as spectacle" (262).

${ }^{6}$ On Vernon's career, see Pevere and Dymond 103.

${ }^{7} \mathrm{I}$ base this comment on several experiences of screening the film to Ontario students.

${ }^{8}$ The Suburbanators even contains an allusion to a classic modernist literary text, as if to demonstrate slyly that strategies of subtlety and allusiveness can work just as well in suburbia as anywhere else. Like The Hours, although more fleetingly, Burns's film draws on Virginia Woolf's Mrs Dalloway: its assorted characters, like Woolf's, are linked spatially by shared interest in the activities of an aircraft which circles above them, advertising in the sky, although the product being advertised turns out to be a local television station's nightly broadcasts of reruns of $M^{*} A^{*} S^{*} H$.

${ }^{9}$ The work of Douglas Coupland, probably Canada's best-known and most exportable chronicler of suburban/slacker life, also draws heavily on poetic and dramatic modes-as in, for example, the surreally utopian ending of Shampoo Planet.

${ }^{10}$ Felperin describes Mallrats as "clearly too much under studio-financed control" but also praises its "canny observation about how food courts and comicbook stores can be territorial markers in suburban space" (18).

${ }^{11}$ The mundanity of the setting here-a General Motors transit bus, whose turn-signal can be heard clicking gently as the sequence ends-serves in itself to comment glancingly on the unreality of Hollywood films like Speed, which puts a similar bus through improbable stunts.

${ }^{12}$ On the hybridities and hybrid potentials of suburbia, see Silverstone 7-12.

${ }^{13}$ Fox is also noteworthy as an icon, in his role as teenage entrepreneur Alex P. Keaton on Family Ties, of a conservatism often associated with suburbia. On Fox, see Pevere and Dymond 96.

${ }^{14}$ On such films as Srinivas Krishna's Masala, Mina Shum's Double Happiness, and Clement Virgo's Rude, see Gittings 231-262.

${ }^{15}$ The biases of Cops are exposed in one of the many telling sequences in Michael Moore's Bowling for Columbine, in which Moore gets one of the show's producers-a selfdescribed "liberal"- to admit that he "doesn't know how to tell" stories focusing on tolerance rather than on violence.

${ }^{16}$ Moore's film offers considerable evidence of suburban paranoia in the U.S., but its depiction of contrasting Canadian attitudes relies mainly on a sequence in which the filmmaker visits an unidentified Toronto neighborhood and discovers a number of homes with unlocked doors, thereby proving only that some Torontonians are relatively unconcerned about home 
security.

${ }^{17}$ More encouragingly, the city of Calgary has taken innovative environmental measures: since 2001, the light rail transit system that links several of the city's main suburban areas to the downtown core has been powered by energy generated by wind turbines ("Ride the Wind").

${ }^{18}$ Mainstream American film treatments of suburbia are certainly not without all appreciation of the possibilities of understatement. Sam Mendes's American Beauty, for example, despite its deployment of substantial amounts of violence, nudity, and other plot-driving elements, sustains a notable commentary on the incidental pleasures of ordinary aspects of life in quiet residential neighborhoods: suburbia, it suggests, has its contribution to make to "American beauty."

\section{Works Cited}

American Beauty. Dir. Sam Mendes. DreamWorks SKG, 1999.

Archer, John. "Colonial Suburbs in South Asia, 1700-1850, and the Spaces of Modernity." Visions of Suburbia. Ed. Roger Silverstone. London: Routledge, 1997. 26-54.

Back to the Future. Dir. Robert Zemeckis. Amblin/Universal, 1985.

Bogosian, Eric. SubUrbia. New York: Theatre Communications Group, 1995.

Bowling for Columbine. Dir. Michael Moore. Alliance Atlantis/Dog Eat Dog Films/Salter Street Films/United Broadcasting/VIF 2, 2002.

Burns, Gary. "Director's Statement." The Suburbanators . . beneath generation x. 2002 $<$ www.canuck.com/esalon/burns/burns3.html>.

Coupland, Douglas. Shampoo Planet. New York: Pocket Books, 1992.

Cunningham, Michael. The Hours. New York: Farrar, Straus \& Giroux, 1998.

Double Happiness. Dir. Mina Shum. British Columbia Film Commission/Fine Line Films/

First Generation Films/National Film Board of Canada/New Views Films/Telefilm Canada, 1994.

Feldman, Seth. "The Silent Subject in English Canadian Film." Take Two: A Tribute to Film in Canada. Ed. Feldman. Toronto: Irwin Publishing, 1984. 48-57.

Felperin, Leslie. "Close to the Edge." Sight and Sound Oct. 1997: 14-18.

Gittings, Christopher E. Canadian National Cinema. London: Routledge, 2002.

Harries, Dan. Film Parody. London: BFI, 2000.

The Hours. Dir. Stephen Daldry. Miramax Films/Scott Rudin Productions, 2002.

Jurca, Catherine. White Diaspora: The Suburb and the Twentieth-Century American Novel.

Princeton, NJ: Princeton University Press, 2001.

Kitchen Party. Dir. Gary Burns. Cadence Entertainment, 1997.

MacCannell, Dean. "New Urbanism' and its Discontents." Giving Ground: The Politics of Propinquity. Ed. Joan Copjec and Michael Sorkin. London: Verso, 1999. 106-128.

Magder, Ted. Canada's Hollywood: The Canadian State and Feature Films. Toronto: University of Toronto Press, 1993.

Mallrats. Dir. Kevin Smith. Alphaville Films/Universal Pictures/View Askew Productions, 1995.

Maltby, Richard, and Ian Craven. Hollywood Cinema. Oxford: Blackwell, 1995.

Manning, Frank E. "Reversible Resistance: Canadian Popular Culture and the American Other." The Beaver Bites Back?: American Popular Culture in Canada. Ed. David H. Flaherty and Manning. Montreal: McGill-Queen's University Press, 1993. 3-28.

Masala. Dir. Srinivas Krishna. Divani Films/Ontario Arts Council/Ontario Film Development Corporation/Telefilm Canada, 1992. 
Matthews, Nicole. "Kitsch on the Fringe: Suburbia in Recent Australian Comedy Film." Expanding Suburbia: Reviewing Suburban Narratives. Ed. Roger Webster. New York: Berghahn, 2000. 173-185.

McCormick, Kathy. "Builders warned about sprawl." Calgary Herald 8 Mar. 2003: HS03.

McIntosh, David. "Vanishing Point: Proliferations, Purifications, and the Convergence of Canadian and Mexican National Cinemas." Canadian Journal of Film Studies 10.2 (Fall 2001): 59-79.

Monk, Katherine. Weird Sex \& Snowshoes, and Other Canadian Film Phenomena. Vancouver: Raincoast, 2001.

Morson, Gary Saul, and Caryl Emerson. Mikhail Bakhtin: Creation of a Prosaics. Stanford: Stanford University Press, 1990.

Munro, Alice. "The Shining Houses." Dance of the Happy Shades. Toronto: McGraw-Hill, 1968. 19-29.

Nobody Waved Good-Bye. Dir. Don Owen. National Film Board of Canada, 1964.

Owen, Don. Nobody Waved Good-Bye. Ed. Herman Voaden. Toronto: Gage, 1971.

Pevere, Geoff, and Greig Dymond. Mondo Canuck: A Canadian Pop Culture Odyssey. Scarborough, ON: Prentice-Hall Canada, 1996.

Pierson, John. Spike, Mike, Slackers and Dykes: A Guided Tour Across a Decade of American Independent Cinema. New York: Hyperion/Miramax, 1995.

Rebel Without a Cause. Dir. Nicholas Ray. Warner, 1955.

"Ride the Wind." Calgary Transit \& the Environment. $2003<\mathrm{http}$ //www.calgarytransit.com/ environment/ride d wind.html $>$.

Rude. Dir. Clement Virgo. Conquering Lion Productions/KJMB, 1995.

Silverstone, Roger. Introduction. Visions of Suburbia. Ed. Silverstone. London: Routledge, 1997. 1-25.

Slacker. Dir. Richard Linklater. Detour Film Production, 1991.

The Suburbanators. Dir. Gary Burns. Burns Film/Red Devil Films, 1995.

SubUrbia. Dir. Richard Linklater. Castle Rock/Detour Film Production, 1996.

Unfinished Business. Dir. Don Owen. Canadian Broadcasting Corporation/Zebra Films, 1984.

Unifast by United Piece Dye Works. Advertisement. Life 9 Apr. 1956: 19.

Waking Life. Dir. Richard Linklater. Detour Film Production/Flat Black Films/Independent Film Channel/Line Research/Thousand Words, 2001.

Webster, Roger. "Introduction: Suburbia Inside Out." Expanding Suburbia: Reviewing Suburban Narratives. Ed. Webster. New York: Berghahn, 2000. 1-13.

Wool. Advertisement. Life 12 Sept. 1955: 158-159.

Woolf, Virginia. Mrs. Dalloway. New York: Harcourt, Brace \& Co., 1925. 